\title{
PEMBELAJARAN PECAHAN BERBASIS PEMECAHAN MASALAH UNTUK MELATIH BERPIKIR KREATIF PADA SISWA KELAS IV SEKOLAH DASAR
}

\author{
${ }^{1}$ Ayu Wulandari, ${ }^{2}$ Mega Teguh Budiarto, ${ }^{3}$ Agung Lukito \\ ${ }^{1}$ Mahasiswa Program Pascasarjana, Prodi Pendidikan Dasar, Universitas Negeri Surabaya, \\ ${ }^{2 \& 3}$ Dosen Pascasarjana, Prodi Pendidikan Dasar, Universitas Negeri Surabaya \\ e-mail: ayuw.missung@gmail.com
}

Received : November 2017

Reviewed: Desember 2017

Accepted : Januari 2018

Published : Januari 2018

\section{ABSTRACT}

This research aims to develop a math learning tool to train grade fourth students to creative thinking. This development research uses 4-D model that is definition, design, and development, while stage of distribution is not executed. Data collection technique uses observation, test, and questionnaire. Subject in this research is grade fourth students of SDI Raden Patah Surabaya school year 2015/2016. Result of validation indicates that the learning tool overall obtains minimum score of 3 with valid category and can be used with a few revision. Teachers' ability in conducting learning fulfills minimum score of 3 with good performed category. Activity of students overall is in accordance with a determined ideal time and behavior of doing/finishing problem solving is the most dominant behavior. N-Gain Score: $72 \%$ of the students is in high category, $28 \%$ of the students is in medium category, and none of the students who obtains $N$-Gain Score in low category. Data of students respond indicates that the majority of the students (79.52\%) enjoy learning of problem solving based fraction. Based on the result of the research, as a main base, it can be concluded that the developed learning tool can be stated as a valid, practice, and effective learning tool. Implication of the research that can be drawn is that learning of problem solving based fraction can train the students to creative thinking. The learning tool of problem solving based fraction can be alternative to train the grade fourth students of SDI Raden Patah Surabaya to creative thinking on the topic of fraction.

Keywords: Problem Solving, Creative Thinking.

\section{ABSTRAK}

Penelitian ini bertujuan untuk mengembangkan perangkat pembelajaran Matematika untuk melatih berpikir kreatif siswa kelas IV SD. Penelitian pengembangan ini menggunakan model 4-D yaitu pendefinisian, perancangan, dan pengembangan, sedangkan pada tahap penyebaran tidak dilakukan. Teknik pengumpulan data menggunakan observasi, tes, dan angket. Subjek dalam penelitian ini adalah siswa kelas IV SDI Raden Patah Surabaya Tahun Ajaran 2015/2016. Hasil dari validasi menunjukkan bahwa perangkat pembelajaran secara keseluruhan memperoleh skor minimal 3 dengan kategori valid dan dapat digunakan dengan sedikit revisi. Kemampuan guru dalam melaksanakan pembelajaran memenuhi skor minimal 3 dengan kategori terlaksana dengan baik. Aktivitas siswa secara keseluruhan sesuai dengan kriteria waktu ideal yang ditentukan dan perilaku mengerjakan/menyelesaikan pemecahan masalah adalah perilaku yang paling dominan. N-Gain Score $72 \%$ siswa pada kategori tinggi, $28 \%$ siswa pada kategori sedang, dan tidak ada siswa yang mendapat N-Gain Score pada kategori rendah. Data respon siswa menunjukkan mayoritas siswa $(79,52 \%)$ senang terhadap pembelajaran pecahan berbasis pemecahan masalah.Berdasarkan hasil penelitian sebagai dasar utama dapat disimpulkan bahwa perangkat pembelajaran yang dikembangkan dapat dinyatakan sebagai perangkat pemebalajaran yang valid, praktis, dan efektif. Implikasi penelitian yang dapat ditarik adalah pembelajaran pecahan berbasis pemecahan masalah dapat melatih 
keterampilan berpikir kreatif siswa. Perangkat pembelajaran pecahan berbasis pemecahan masalah dapat menjadi alternatif untuk melatih berpikir kreatif siswa kelas IV SD pada topik pecahan.

Kata Kunci: Pemecahan Masalah, Berpikir Kreatif.

\section{PENDAHULUAN}

Pendidikan merupakan upaya untuk memberikan bekal kepada seseorang agar mampu menghadapi perubahan yang disebabkan oleh kemajuan ilmu pengetahuan dan teknologi. Matematika menjadi semakin penting dalam era sekarang karena kecenderungan matematika akan berlanjut untuk seterusnya ke masa yang akan datang karena matematika sebagai alat untuk memecahkan masalah secara riil.

Siswono (2008:1), menyatakan bahwa perkembangan teknologi dan informasi pada saat ini tidak dapat dipungkiri merupakan buah dari kemampuan berpikir kreatif manusia. Hal ini membuat seseorang harus mempunyai keterampilan berpikir kreatif untuk mampu bersaing dan membuat setiap individu berkesempatan menciptakan ide-ide baru yang belum ada sebelumnya serta dianggap berguna bagi masyarakat.

Di sisi lain, banyaknya pengangguran membuktikan banyak individu yang mengalami kegagalan dalam bersaing, ini dikarenakan kemampuan berpikir kreatifnya rendah sehingga mudah untuk menyerah ketika menghadapi permasalahan. Oleh karena itu, untuk bersaing pada era modernisasi ini, individu harus dibekali dengan kemampuan berpikir kreatif mulai sejak dini, khususnya di tingkat sekolah dasar.

Usaha yang dilakukan untuk mendorong kemampuan berpikir kreatif sebagai bekal hidup untuk menghadapi tuntutan dan perkembangan zaman melalui pendidikan yang berkualitas. Pendidikan tersebut dapat mengarahkan siswa menjadi pelajar yang kreatif. Kemampuan berpikir kreatif dalam diri siswa dapat dikembangkan melalui pembelajaran matematika. Hal ini sesuai dengan Permendikbud tahun 2006 bahwa mata pelajaran mate matika perlu diberikan kepada semua siswa mulai dari sekolah dasar untuk membekali siswa dengan kemampuan berpikir logis, analisis, sistematis, kritis, dan kreatif.

Tidak dapat dipungkiri matematika merupakan dasar ilmu universal yang sangat dibutuhkan karena erat kaitannya dengan kehidupan sehari-hari. Matematika di dalam pendidikan formal (sekolah) merupakan salah satu mata pelajaran yang diajarkan di semua jenjang pendidikan, baik SD, SMP, SMA maupun perguruan tinggi. Pembelajaran matematika akan mengarahkan siswa menjadi pembelajar yang berkualitas dan kreatif dalam kehidupan sehari-hari pada masa depan yang kompetitif. Mengingat keluaran yang diharapkan tersebut bisa terwujud bila dalam proses pembelajaran peserta didik terlibat aktif dan diberi kesempatan mengembangkan potensi-potensinya untuk berpikir kreatif.

Sudarma (2013:17) menyatakan bahwa keterampilan berpikir kreatif adalah kemampuan melahirkan ide atau gagasan baru atau gagasan kreatif mengenai sesuatu hal. Berpikir kreatif berarti memandang sesuatu dari bebagai macam sudut pandang yang berbeda dengan berbagai kemungkinan yang ada. Berpikir kreatif sangat berpengaruh pada kehidupan sehari-hari dan bisa menjadi penentu kesuksesan di masa depan, oleh karena itu, keterampilan berpikir kreatif perlu diberikan sejak dini sebagai bekal menghadapi tuntutan persaingan dan kemajuan zaman. Nur (2014:1) menyatakan bahwa kreativitas dan inovasi merupakan "darah" yang penting untuk hidup dalam ekonomi global dan sesungguhya merupakan prioritas stategis bagi Chief Executive Officer (CEO) di seluruh dunia.

Berpikir kreatif adalah perwujudan dari berpikir tingkat tinggi. Hal ini karena berpikir kreatif merupakan kompetensi kognitif tertinggi. Berpikir kreatif dapat dipandang sebagai suatu proses yang digunakan ketika seorang individu memunculkan suatu ide baru sebagai hasil dari proses berpikir. Pehkonen (dalam Siswono 2008:3), menyatakan berpikir kreatif dalam matematika diartikan dengan kombinasi berpikir logis dan berpikir divergen yang didasarka intuisi tetapi masih dalam kesadaran. Kemampuan berpikir kreatif tidak hanya meningkatkan kecakapan akademik, tetapi juga kecakapan personal (kesadaran diri dan keterampilan berpikir) dan sosial.

Perlunya berpikir kreatif dimaksudkan agar siswa mampu menyelesaikan masalah secara rasionalitas dalam dunia nyata. Untuk mendukung hal tersebut, siswa tidak cukup hanya diasah kemampuan berpikir secara teoritis dan kritisnya saja tetapi harus diajak untuk berpikir tingkat tinggi yang diarahkan pada kemampuan berpikir kreatif. Menurut Siswono (2008:3) "bepikir kritis dan kreatif merupakan suatu kesatuan". Sehingga guru yang mengajar matematika perlu menekankan berpikir kritis dan kreatif dalam mendesain pembelajaran untuk memecahkan masalah secara teoritis dan efektif.

Dalam pembelajaran di dalam kelas, keterampilan berpikir kreatif juga memiliki pengaruh positif. Penelitian 
yang dilakukan di SDN 001 Sangatta Selatan, Kutai menunjukkan bahwa keterampilan berpikir kreatif memiliki pengaruh positif terhadap perstasi belajar matematika (Ramadin: 2013).

Pembelajaran matematika yang berlangsung di kelas seharusnya dapat mengarahkan kemampuan berpikir kreatif siswa, namun kenyataan di lapangan pembelajaran yang dilakukan cenderung masih berpola konvensional. Belum adanya perangkat pembelajaran yang menekankan berpikir kreatif dalam matematika. Lembar Kegiatan Siswa (LKS) yang digunakan juga masih menekankan pada penguasaan konsep dengan tidak memberikan kebebasan siswa untuk berpikir secara mandiri dan kreatif. Kenyataan lainnya, hampir di setiap jenjang pendidikan, matematika dianggap sebagai mata pelajaran yang sulit, menakutkan dan bahkan menjadi momok tersendiri bagi siswa. Tidak banyak siswa yang menyukai mata pelajaran matematika jika dibandingkan dengan mata pelajaran lainnya. Kondisi yang demikian sulit untuk mendorong meningkatkan kemampuan berpikir kreatif siswa, sehingga diperlukan adanya perangkat pembelajaran yang mendukung agar tujuan pembelajaran dapat tercapai dengan baik.

Menurut Sumarmo (2012:4), pembelajaran matematika pada hakekatnya memiliki dua arah pengembangan, yaitu untuk memenuhi kebutuhan masa kini dan masa yang akan datang. Kebutuhan masa kini yaitu kebutuhan yang mengarah pada kemampuan pemahaman konsep-konsep yang diperlukan untuk menyelesaikan masalah matematika dan ilmu pengetahuan lainnya, sedangkan kebutuhan masa datang adalah kebutuhan yang mengarah pada kemampuan nalar yang logis, sistematis, kritis, kreatif, dan cermat serta berpikir terbuka untuk menghadapi masa depan yang selal berubah.

Kenyataannya, proses-proses pemikiran tinggi termasuk berpikir kreatif jarang dilatihkan apalagi di jenjang sekolah dasar. Pembelajaran matematika di sekolah dasar selama ini lebih menekankan pada hafalan dan mencari jawaban yang benar terhadap permasalahn yang diberikan.

Menindaklanjuti hal tersebut, perlu dilakukan pengembangan peningkatan mutu dalam pembelajaran matematika yang dapat malatih kemampuan berpikir kreatif siswa melalui pembelajaran, salah satunya pembelajaran berbasis pemecahan masalah untuk melatih berpikir kreatif.

Pemecahan masalah menurut Djamarah (2010:91), pemecahan masalah bukan hanya sekadar pendekatan mengajar, namun juga merupakan suatu pendekatan berpikir, sebab dalam pemecahan masalah dapat mengguanakan metode lain yang dimulai dari mengumpulkan data sampai menarik kesimpulan. Reys (2004:108) mengungkapkan bahwa pemecahan masalah dalam pembelajaran matematika merupakan keterampilan yang diperlukan oleh seseorang. Di sekolah, siswa diharapkan mampu memecahkan masalah agar dapat memahami konsep-konsep matematika, menemukan hubungan baru, dan membuat hubungan matematika dengan mata pelajaran lain. Sedangkan dalam kehidupan sehari-hari, anak-anak dan orang dewasa mengahadapi masalah sebagai konsumen, warga negara dan pekerja.

Pemecahan masalah dipilih karena melalui pendekatan pemecahan masalah dapat melatih berpikir kreatif siswa . Pendekatan pemecahan masalah ini melibatkan emosi siswa selama proses pemecahan masalah yang membuat siswa merasa penasaran sehingga dapat meningkatkan motivasi siswa dalam belajar matematika. Susanto (2013:203) mengungkapkan bahwa pendekatan pemecahan masalah merupakan suatu cara pemecahan masalah yang langkah-langkahnya dirancang untuk memudahkan siswa berpikir untuk menemukan pola pemecahan yang tepat. Lingkungan belajar yang aktif melibatkan siswa dalam menggali informasi dan menerapkan pengetahuan yang dimiliki dapat meningkatkan kemampuan berpikir kreatif siswa.

Pada materi pecahan siswa dapat menemukan berbagai alternatif jawaban dan cara penyelesaian. Selain itu pecahan juga dekat dengan kehidupan sehari-hari siswa. Oleh karena itu, materi pecahan cocok untuk melatih berpikir kreatif siswa dengan menggunakan pemecahan masalah.

Pada kurikulum 2013 ini, pecahan merupakan salah satu topik/materi pada siswa SD Kelas IV di semester II ini. Di samping itu, siswa kelas IV SD sudah mampu berpikir tingkat tinngi, sehingga dapat dilatihkan berpikir kreatif. Oleh karena itu peneliti memilih siswa kelas IV SD sebagai subjek penelitian.

Untuk menunjang implementasi pembelajaran ini tentu tidak bisa terlepas dari instrumen-instrumen pembelajaran yang tertuang dalam perangkat pembelajaran dengan memfokuskan untuk melatih berpikir kreatif siswa. Atas dasar itulah perlu dikembangkan instrumen pembelajaran untuk melatih berpikir kreatif. Tujuan dari penelitian ini adalah untuk mendeskripsikan hasil pengembangan instrumen pembelajaran serta mendeskripsikan keefektifan instrumen pembelajaran.

\section{METODE}

Jenis penelitian ini adalah penelitian pengembangan yaitu pengembangan perangkat. Pengembangan perangkat pembelajaran mengikuti 4-D model design yang 
menyatakan bahwa proses pengembangan perangkat model 4-D terdiri atas define, design, develop, dan desseminate (Thiagarajan, 1974). Proses tersebut dilakukan sampai pada tahap pengembangan saja. Proses tersebut meliputi:

\section{Tahap Pendefinisian}

Tujuan tahap define adalah untuk menetapkan dan mendefinisikan syarat-syarat pembelajaran. Tahap ini terdiri dari 5 langkah pokok yaitu, analisis awal akhir, analisis siswa, analisis tugas, analisis konsep dan perumusan tujuan.

Analisis awal akhir bertujuan untuk memunculkan dan menetapkan masalah dasar yang dihadapi dalam pembelajaran, sehingga dibutuhkan pengembangan bahan pembelajaran. Dalam melakukan analisis awal akhir perlu mempertimbangkan beberapa hal sebagai alternatif pengembangan bahan pembelajaran, teori belajar, tantangan dan tuntutan masa depan. Hal ini dapat dilakukan dengan menganalisis kondisi yang ada di lapangan untuk mengetahui kesenjangan antara harapan dan tuntutan yang membutuhkan adanya pengembangan perangkat pembelajaran pada mata pelajaran Matematika.

Analisis siswa merupakan telaah karakteristik siswa yang meliputi kemampuan atau keterampilan, latar belakang pengetahuan, dan tingkat perkembangan kognitif siswa. Karakteristik peserta didik yang ingin diketahui yaitu kemampuan akademik individu, kemampuan kerja kelompok, motivasi belajar, pengalaman belajar sebelumnya, dll yang sesuai dengan tujuan penelitian. Analisis siswa dapat diketahui berdasarkan riwayat belajar siswa dan nilainilai siswa yang dimiliki oleh guru.

Analisis tugas adalah kumpulan prosedur untuk menentukan isi dalam satuan pembelajaran. Analisis tugas dilakukan untuk merinci isi materi ajar dalam bentuk garis besar. Dalam analisis tugas ini diketahui standar kompetensi, kompetensi dasar dan gambaran materi yang akan dijadikan acuan dalam pengembangan bahan ajar.

Analisis konsep merupakan identifikasi konsep-konsep utama yang akan diajarkan dan menyusunnya secara sistematis serta mengaitkan satu konsep dengan konsep lain yang relevan, sehingga membentuk suatu peta konsep. Peneliti menganalisis materi dengan cara mengidentifikasi materi utama yang perlu diajarkan, mengumpulkan dan memilih materi yang relevan dan menyusunnya kembali secara sistematis. Hasil dari analisis konsep berupa peta konsep dari materi yang digunakan dalam pengembangan bahan ajar.
Dalam perumusan tujuan pembelajaran ditentukan indikator- indikator pencapaian tujuan atau hasil belajar dengan mengembangkan kompetensi dasar yang ada. Selanjutnya indikator yang telah terbentuk dijadikan acuan untuk merumuskan tujuan pembelajaran. Hal ini dilakukan untuk membatasi peneliti agar tidak menyimpang dari tujuan awal. Hasil dari perumusan tujuan berupa tujuan pembelajaran yang menggunakan bahan ajar yang akan dikembangkan.

\section{Tahap Perancangan}

Tahap design merupakan tahapan perancangan yang bertujuan untuk menyiapkan prototipe perangkat pembelajaran. Tahap pertama yaitu penyusunan tes. Pada tahap ini, peneliti menyusun tes berupa tes kognitif atau hasil belajar dan tes keterampilan berpikir kreatif.

Tahap selanjutnya yaitu pemilihan format. Format yang dipilih adalah yang memenuhi kriteria menarik, memudahkan dan membantu siswa dalam pembelajaran. Tahap rancangan awal produk yang dikembangkan dilakukan peneliti dengan mendesain perangkat pembelajaran pecahan berbasis pemecahan masalah yang disesuaikan dengan kerangka isi hasil analisis kurikulum dan menyiapkan perangkat pembelajaran pecahan berbasis pemecahan masalah. Peneliti juga mempersiapkan media yang dibutuhkan selama proses pembelajaran serta media atau alat dan bahan yang dibutuhkan dalam penggunaan perangkat pembelajaran pecahan berbasis pemecahan masalah. Hasil dari rancangan awal berupa perangkat pembelajaran pecahan berbasis pemecahan masalah untuk melatih keterampilan berpikir kreatif.

\section{Tahap Pengembangan}

Tahap develop atau pengembangan bertujuan untuk menghasilakan produk pembelajaran yang sudah direvisi berdasarkan masukan dari para pakar. Tahap pertama, dilakukan dengan cara menguji isi dan keterbacaan perangkat pembelajaran kepada pakar atau ahli materi dari bidang matematika yang biasa disebut dengan telaah perangkat pembelajaran oleh ahli materi. Tahap selanjutnya yaitu uji validasi dilakukan oleh pakar atau ahli materi dari bidang matematika pada perangkat pembelajaran yang telah diperbaiki untuk menguji kelayakan dari perangkat pembelajaran yang telah dikembangkan tersebut. Uji coba terbatas dilakukan dua kali terhadap siswa skala kecil dan skala yang lebih luas sesuai dengan kelas sesungguhnya. Tujuan dari uji coba terbatas adalah untuk mendapatkan informasi apakah penggunaan perangkat pembelajaran 
berbasis pemecahan masalah ini lebih efektif dan efesien dalam peningkatan hasil belajar siswa dibandingkan dengan penggunaan perangkat pembelajaran yang lama. Selanjutnya Implementasi produk berupa perangkat pembelajaran berbasis pemecahan masalah yang dilakukan di kelas yang berbeda. Implementasi produk dilakukan untuk mengetahui apakah penggunaan perangkat pembelajaran berbasis pemecahan masalah ini lebih efektif dibandingkan dengan penggunaan perangkat pembelajaran yang lama. Indikator dari efektivitas perangkat pembelajaran berbasis pemecahan masalah yaitu siswa mampu berpikir kreatif minimal memenuhi indikator fleksibilitas.

Sasaran dalam penelitian ini adalah perangkat pembelajaran yang diuji cobakan pada siswa kela IV SDI Raden Patah. Instrumen penelitian yang digunakan antara lembar validasi perangkat, lembar pengamatan pengelolaan kelas, lembar pengamatan aktivitas siswa, angket respon siswa, dan tes hasil belajar.

Teknik analisis data yang digunakan adalah kuantitatif. dan berikutnya hasil analisis deskriptif akan dideskripsikan secara kualitatif. Analisis perangkat pembelajaran meliputi silabus, RPP, LKS, dan TBK. Perangkat Pembelajaran layak dan dapat digunakan jika penilaian validator minimal 3 dengan kategori B (baik).

Keterlaksanaan pembelajaran dilakukan dengan mengamati pembelajaran dengan mengacu lembar pengamatan yang telah diberikan.

Aktivitas siswa dihitung dari perolehan rata-rata aspek pengamatan dibagi dengan banyaknya rata-rata semua aspek kemudian dikalikan 100\%. Hasil aktivitas siswa diintepreatsikan pada Tabel 1.

Tabel 1

\begin{tabular}{lcccc}
\hline $\begin{array}{l}\text { Aspek Pengamatan } \\
\text { Aktivitas Siswa }\end{array}$ & $\mathbf{A}$ & $\begin{array}{c}\text { B } \\
(\boldsymbol{\%})\end{array}$ & $\begin{array}{c}\text { C } \\
(\boldsymbol{\%})\end{array}$ & $\mathbf{D}(\%)$ \\
$\begin{array}{l}\text { Mendengarkan/memper } \\
\text { hatikan penjelasan guru. }\end{array}$ & 10 & 14,2 & 1,42 & $12,7 \leq \mathrm{P} \leq 15,6$. \\
$\begin{array}{l}\text { Melakukan perencanaan } \\
\text { pemecahan masalah. }\end{array}$ & 10 & 14,2 & 1,42 & $12 \leq \mathrm{P} \leq 15,6$ \\
$\begin{array}{l}\text { Mengerjakan/menyelesa } \\
\text { ikan pemecahan }\end{array}$ & 20 & 28,5 & 2,85 & $25,6 \leq \mathrm{P} \leq 31,3$ \\
$\begin{array}{l}\text { masalah. } \\
\begin{array}{l}\text { Berdiskusi/bertanya } \\
\text { dengan siswa atau guru. }\end{array}\end{array}$ & 10 & 14,2 & 1,42 & $12,7 \leq \mathrm{P} \leq 15,6$ \\
$\begin{array}{l}\text { Memeriksa kembali } \\
\text { hasil kerja sebelum } \\
\text { dikumpulkan. }\end{array}$ & 10 & 14,2 & 1,42 & $12 \leq \mathrm{P} \leq 15,6$. \\
$\begin{array}{l}\text { Menulis/mencatat yang } \\
\text { terkait dengan kegiatan } \\
\text { pembelajaran }\end{array}$ & 10 & 14,2 & 1,42 & $12 \leq \mathrm{P} \leq 15,6$ \\
$\quad$ Jumlah & & & & \\
\hline
\end{tabular}

\section{HASIL DAN PEMBAHASAN}

Paparan hasil penelitian mencakup (1) hasil pengembangan, (2) dan keefektivan perangkat pembelajaran.

Grafik 1 Hasil Pengembangan

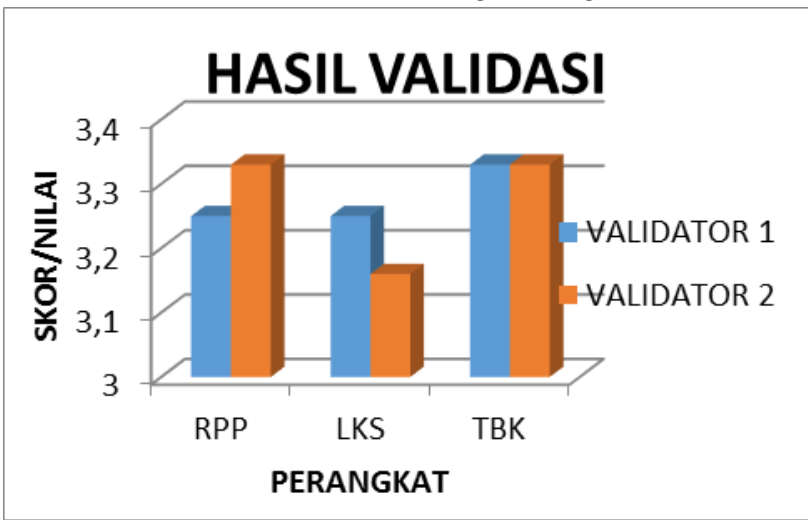

RPP merupakan panduan penting dalam melaksanakan suatu pembelajaran, maka dari itu pendidik diwajibkan untuk menyusun RPP. Hal ini dimaksudkan agar terciptanya pembelajaran yang efektif, interaktif, inspiratif, menyenangkan, efisien, memotivasi peserta didik untuk berpartisipasi aktif, serta mengembangakn keterampilan berpikir seperti berpikir kritis dan kreatif.

Penyusunan RPP ini mengacu pada kurikulum 2013, yang harus memuat kompetensi inti, kompetensi dasar, indikator, tujuan pembelajaran, alokasi waktu, materi, metode pembelajaran, kegiatan pembelajaran dan sumber belajar. RPP yang dikembangkan dibuat dalam tiga kali pertemuan. Hal ini sesuai dengan peraturan Permenikbud No. 65 Tahun 2013 tentang satandar proses, rencana pelaksanaan pembelajaran (RPP) adalah kegiatan pembelajaran tatap muka untuk satu pertemuan atau lebih.

LKS yang dikembangkan mengikuti pola pembelajaran pemecahan masalahuntuk melatih berpikir kreatif. Sebelum diujicobakan, LKS yang dikembangkan divalidasi oleh validator. Hasil validasi disajikan pada Tabel 4.3 skor yang didapat memenuhi skor minimal yaitu 3 dengan kategori valid.

Selain hasil validasi yang berupa nilai, validator juga memberikan saran dan masukan untuk membuat LKS yang dikembangkan menjadi lebih baik lagi. Saran yang diberikan oleh validator yaitu untuk memberi gambar yang sesuai, memberi ruang lebih untuk pengerjaan serta memperbaiki tata kalimat soal yang bermakna ganda. LKS yang digunakan dalam kegiatan pembelajaran pecahan berbasis pemecahan masalah adalah untuk melatih siswa dalam berpikir kreatif. 
Tes berpikir kreatif disusun berdasarkan indikator yang diadaptasi dari Torrance yakni kefasihan, fleksibilitas, kebaruan dan ellaboration. Dalam penelitian ini hanya menggunakan 3 indikator yaitu, kefasihan, fleksibilitas, dan kebaruan. Kefasihan yang dimaksudkan adalah siswa mampu memberikan beberapa jawaban yang berbeda dan bernilai benar. Fleksibilitas, siswa mampu mencetuskan banyak cara dengan jawaban benar dari suatu masalah. Fleksibilitas mampu menghasilkan cara yang bervariasi dengan jawaban benar, sehingga siswa berlatih untuk melihat suatu masalah dari sudut pandang yang berbeda. Kebaruan adalah siswa mampu memikirkan cara yang tidak biasa digunakan dan benar.

Indikator yang disusun ini sesuai dengan empat komponen kreatifitas dari Munandar (2012), yaitu; (1) Fluency yaitu kemampuan untuk menghasilkan sejumlah ide, (2) Flexibility yaitu kemampuan untuk menghasilkan ide-ide yang beragam, (3) originality yakni kemampuan untuk menghasulkan ide yang tak biasa, dan (4) elaboration yaitu kemampuan untuk mengembangkan atau mengeluarkan sebuah ide. Dalam penelitian ini yang diukur adalah kemampuan berpikir kreatif siswa dalam menyelesaikan masalah yang berhubungan dengan materi. Yang diukur dalam penelitian ini meliputi kelancaran, keluwesan dan kebaruan. Kefasihan dalam penelitian ini diukur dalam jumlah banyaknya siswa menjawab pertanyaan yang logis. Fleksibilitas aspek yang diukur dari jawaban siswa yang bervariasi. Dan aspek kebaruan yang diukur dalam penelitian ini adalah keberbedaan jawaban siswa dengan siswa lain. Jawaban siswa dikatakan baru jika siswa mampu memberikan jawaban yang tidak dijawab degan siswa lain dan benar.

Perhitungan reliabilitas tes berpikir kreatif mendapatkan hasil 0,633. Dengan demikian tes berpikir kreatif mempunyai reliabilitas sedang. Atas dasar perhitungan tersebut maka tes berpikir kreatif dapat digunakan untuk mengukur tingkat kreatifitas siswa terhadap pecahan.

Tabel 2 Hasil Tes Berpikir Kritis

\begin{tabular}{cc} 
Cronbach's Alpha & N of Items \\
0,633 & 9 \\
\hline
\end{tabular}

Tingkat sensitivtas dari butir soal merupakan ukuran seberapa baik butir soal itu mampu membedakan antara siswa yang telah menerima pembelajaran pecahan berbasis pemecahan masalah dengan siswa yang belum menerima pembelajaran tersebut.

Perhitungan sensitivitas tes hasil belajar mendapatkan $\geq 0,30$ dengan kategori sensitif. Sensitivitas butir tes hasil belajar siswa secara ringkas disajikan pada tabel di bawah ini.

Tabel 3 Hasil Belajar Siswa

\begin{tabular}{llllllll}
\hline No. & $\mathbf{1 a}$ & $\mathbf{1 b}$ & $\mathbf{1 c}$ & $\mathbf{2 a}$ & $\mathbf{2 b}$ & $\mathbf{3 a}$ & $\mathbf{3 b}$ \\
Hasil & 0,38 & 0,40 & 0,41 & 0,55 & 0,52 & 0,37 & 0,41 \\
\hline
\end{tabular}

Berdasarkan tabel di atas maka dapat dikatakan bahwa sensitivitas tiap butir soal sensitif terhadap pembelajaran karena nilai masing-masing butir soal memenuhi kriteria $\mathrm{S} \geq 0,30$ dengan demikian masingmasing butir soal dianggap layak untuk digunakan.

\section{Keefektivan Perangkat}

a. Keterlaksanaan Pembelajaran

Grafik 2 Keterlaksanaan Pembelajaran

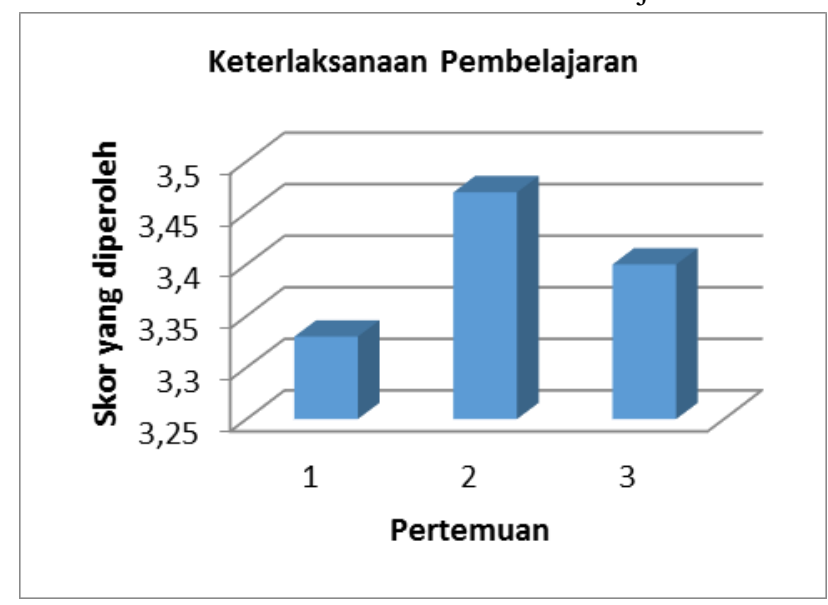

Pelaksaan pembelajaran dilakukan berdasarkan RPP yang telah dikembangkan dengan pendekatan pemecahan masalah yang diintregasikan dengan strategi pemecahan masalah Polya. Terdapat tiga kegiatan diantaranya pendahuluan, kegiatan inti dan penutup. Pemecahan masalahyang dilakukan akan terlihat pada kegiatan inti yakni memahami masalah, merencakan penyelesaian masalah, melakukan penyelesaian masalah, dan memeriksa kembali hasil penyelesaian masalah.

Pada pembelajaran pemecahan masalah, guru dapat memfasilitasi siswa untuk berinovasi, berkreasi sehingga akan melatihkan kemampuan berpikir kreatif. Sejalan dengan pendapat Davies (dalam Suyono, 2011) bahwa salah satu peran dan fungsi guru sebagai titik puncak, guru merancang pembelajaran dari awal sampai akhir, selanjutnya siswa meraih titik puncak berupa keberhasilan dalam pembelajaran. 
b. Aktifitas Siswa

Grafik 3 Aktivitas Siswa

\begin{tabular}{|c|c|c|c|c|c|c|}
\hline & \\
\hline & & \\
\hline & & \\
\hline
\end{tabular}

Pada kegiatan penelitian ini pengamatan aktivitas siswa dilakukan di kelas ujicoba dan implementasi selama 3 kali pertemuan. Hal ini dimaksudkan apakah aktivitas siswa yang melakukan pembelajaran pecahan berbasis pemecahan masalah berlangsung dengan baik atau tidak dan mengetahui aktivitas yang dominan. Penilaian terhadap aktivitas siswa sangat penting, hal ini senada dengan Mulyasa (2009, dengan modifikasi), yang menyatakan, bahwa proses pembelajaran pada hakikatnya untuk mengembangkan aktivitas siswa melalui berbagai interaksi dan pengalaman belajar.

\section{c. Respon Siswa}

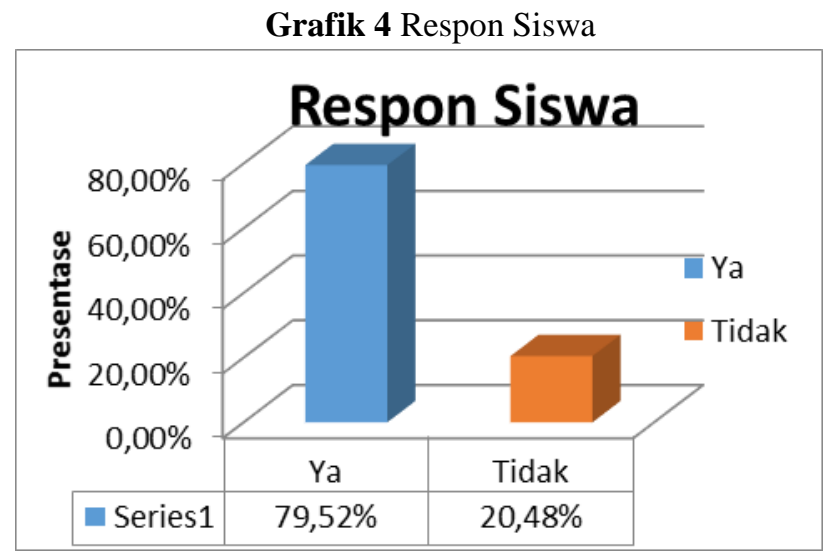

Hasil dari pengembangan perangkat pembelajaran digunakan dapat diketahui bahwa siswa memberi respon positif. Angket yang diberikan kepada siswa ada 10 pertanyaan. Respon siswa memenuhi kriteria $\geq 70 \%$ dengan $79,52 \%$ siswa memberikan respon positif. Sehingga dapat ditarik kesimpulan bahwa respon siswa terhadap pembelajaran pecahan berbasis pemecahan masalah mendapatkan respon positif.

\section{d. Tes Berpikir Kreatif}

Secara umum validator memberikan penialian soal berpikir kreatif termasuk kriteria valid dalam segi isi dan bahasa maupun penulisan, namun ada beberapa soal yang harus diubah kalimatnya sehingga ketika dibaca oleh siswa tidak menimbulkan makna ganda. Dalam penulisan soal berpikir kreatif harus disesuaikan dengan RPP yang telah dibuat dengan pembelajaran pecahan berbasis pemecahan masalah.

Tabel 4 Nilai N-Gain TBK

\begin{tabular}{ccc}
\hline Kategori & $\begin{array}{c}\text { Banyak } \\
\text { Siswa }\end{array}$ & Presentase \\
Tinggi & 15 & $72 \%$ \\
Sedang & 6 & $28 \%$ \\
Rendah & - & - \\
\hline
\end{tabular}

Berdasarkan tabel di atas diketahui $N$-Gain Score sebesar 0,56 dengan kategori sedang. Pada Bab III dijelaskan bahwa pembelajaran dikatakan efektif jika perbedaan keterampilan berpikir kreatif pada kategori sedang dan tinggi. Jadi dapat disimpulkan bahwa pembelajaran berbasis pemecahan masalah efektif karena memenuhi kriteria tersebut

Tes keterampilan berpikir kreatif dilaksanakan pada kelas ujicoba dan kelas implementasi untuk melihat konsistensian terhadap pembelajaran pecahan berbasis pemecahan masalah. Pada kelas ujicoba hasil tes berpikir kreatif yang ditunjukkan oleh tabel 4.14 bahwa rata-rata hasil pretest 5 dan rata-rata hasil postest 11,19 dengan nilai $\mathrm{N}-$ Gain rata-rata kelas ujicoba 0,56 yang berarti peningkatan nilai dari pretest dan postest berkategori sedang. Pada kelas implementasi hasil tes berpikir kreatif yang ditunjukkan oleh tabel 4.19 bahwa rata-rata hasil pretest 6 dan rata-rata hasil postest 11,7 dengan nilai $\mathrm{N}$ Gain rata-rata kelas ujicoba 0,57 yang berarti peningkatan nilai dari pretest dan postest berkategori sedang.

Pada kurikulum 2013 pembelajaran berbasis pemecahan masalah sangat diperlukan. Berdasarkan Tabel 1 dan Tabel 2 menunjukan bahwa kreatifitas siswa meningkat setelah pembelajaran pecahan berbasis pemecahan masalah untuk melatih berpikir kreatif siswa. Karena dengan pembelajaran pemecahan masalah, siswa diharapkan untuk lebih aktif dalam menemukan konsep, berinovasi dan berkreasi dengan masalah yang dihadapi. 
Peningkatan keteramapilan berpikir kreatif tiap siswa berbeda. Tetapi hampir semua siswa mengalami peningkatan dengan range peningkatan yang bervariasi. Hal ini dapat dikatakan bahwa pembelajaran pecahan berbasis pemecahan masalah dapat melatih berpikir kreatif siswa. Menurut Warnock (1976) imajinasi itu tentang kesan-kesan sederhana yang muncul secara original dari waktu yang berbeda. Pada waktu mengerjakan soal berpikir kreatif, siswa akan menuangkan ide yang ada dalam pikiran mereka sesuai imajinasi mereka. Dari hasil penelitian menunjukkan bahwa, pembelajaran pecahan berbasis pemecahan masalah dapat melatih berpikir kreatif siswa.

\section{PENUTUP}

\section{Simpulan}

Berdasarkan pertanyaan penelitian dan pembahasan hasil penelitian yang telah diuraikan, dapat disimpulkan bahwa pengembangan perangkat pembelajaran pecahan berbasis pemecahan masalah untuk melatih berpikir kreatif siswa kelas IV SD dengan menggunakan model pengembangan 4D yang dikembangkan oleh Thiagarajan (1974) yang terdiri atas 4 tahap yaitu define (pendefinisian), design (perancangan), develop (pengembangan), dan disseminate (penyebaran). Namun dalam penelitian pengembangan ini menggunakan model 3-D yaitu define, design dan develop, diperoleh beberapa simpulan sebagai berikut :

1. Perangkat pembelajaran pecahan berbasis pemecahan masalah yang dikembangkan dikategorikan layak dan dapat digunakan. Perangkat pembelajaran telah memenuhi kriteria kevalidan validitas konten dan validitas konstruk, kriteria kepraktisan, dan kriteria keefektifan.

2. Pembelajaran pecahan berbasis pemecahan masalah efektif. Hal ini dapat dilihat dari indikator yang telah ditetapkan, yaitu sebagai berikut:

a. Kemampuan guru mengelola pembelajaran dalam kategori baik.

b. Aktivitas siswa memenuhi kriteria batasan waktu yang ideal sesuai yang sudah ditentukan.

c. Respon siswa terhadap pembelajaran positif dengan persentase $>70 \%$.

d. Tingkat keberhasilan kemampuan berpikir kreatif siswa ditunjukkan dengan skor $\mathrm{N}$-gain mencapai kriteria sedang.

Dari penjabaran di atas, maka dapat diperinci bahwa penelitian ini telah berhasil mengembangkan perangkat pembelajaran yang valid, praktis dan efektif, yang berorientasikan pemecahan masalah dalam pembelajaran pecahan yang efektif untuk melatih berpikir kreatif siswa kelas IV SD.

Saran

Berdasarkan penelitian yang telah dilakukan maka disarankan:

1. Perangkat pembelajaran pecahan berbasis pemecahan masalah dapat digunakan sebagai alternatif perangkat pembelajaran yang efektif untuk melatih berpikir kreatif siswa kelas IV SD pada materi pecahan.

2. Pembelajaran pecahan berbasis pemecahan masalah dapat menjadi alternatif dalam mengajar siswa kelas IV SD pada materi pecahan.

\section{DAFTAR PUSTAKA}

Arifin, Z. 2010. Membangun Kompetensi Pedagogis Guru Matematika. Surabaya: Lentera Cendekia.

Arikunto, S. 2006. Prosedur Penelitian Suatu Pendekatan Praktek. Jakarta: Rineka Cipta.

Arikunto, S. 2013. Dasar-dasar Evaluasi Pendidikan Edisi

2. Jakarta: Bumi Aksara

Chen, F. 2010. Be Creative! Menjadi Pribadi Kreatif 100 Pengertian untuk Mengembangkan Kreativitas. Jakarta: PT Gramedia Pustaka Tama.

Clegg, P. (2008). Creativity and Critical Thinking in The Globalised University. Innovations in Education and Teaching International Vol. 45, No. 3. Taylor $\&$ Francis. [On-Line]. Available FTP: http://web.ebscohost.com/ehost/detail?vid=1\&hid=6 $\&$ sid=faf $35 \mathrm{a} 0 \mathrm{~d}-\mathrm{f5} 65-$

4206b7c25f7bf9b395b6\%40sessionmgr4\&bdata=Jn NpdGU9ZWhvc3QtbG12ZQ\%3

$\mathrm{d} \% 3 \mathrm{~d} \# \mathrm{db}=\mathrm{a} 3 \mathrm{~h} \& \mathrm{AN}=11360368$. Diakses tanggal 10 Januari 2016.

Cooney, T.J., Davis, E.J \& Henderson, K.B. (1975). Dynamics of Teaching Secondary School Mathematics. Boston: Houghton Mifflin Company.

Decendo, F. \& Robin, L. 1999. Mathematics for Elementary Teachers. http://www.emis.de/journals/zdmg73a2.pdf. Diakses tanggal 12 Januari 2016.

Dahar. 2011. Teori-Teori Belajar dan Pembelajaran. Jakarta: Erlangga.

Daryanto \& Dwi C., Arif. 2014. Pengembangan Perangkat Pembelajaran. Yogyakarta: Gava Media.

Lau, J. 2011. An Introduction To Critical Thingking And Creativity Thingking. New Jersey : John Willey \& Son,Inc.

Haylock, D. (1997). Recognizing Mathematical Creativity. Zentralblatt für Didaktik der Mathematik (ZDM). The International Journal on Mathematics 
Education.

[Online].

Tersedia:

http://www.emis.de/journals/ZDM/

zdm973a5.pdf. Diakses 15 Januari 2016.

Heruman. 2007. Model Pembelajaran Matematika Di Sekolah Dasar. Bandung: PT Remaja Rosdakarya.

Hudojo. 1988. Mengajar Belajar Matematika. Jakarta: Proyek Pengembangan Lembaga Pendidikan Tenaga Kependidikan.

Ibrahim, M. 2010. Dasar-dasar Proses Belajar Mengajar. Surabaya: Unesa University Press.

Indarti, T. 2008. Penelitian Tindakan Kelas dan Penulisan Ilmiah. Surabaya: Lembaga Penerbitan FBS UNESA.

Julianto. Teori dan Implementasi Model-Model Pembelajaran Inovatif. Surabaya: Unesa University Press.

Kemendikbud. 2012. Bahan Uji Publik Kurikulum 2013. Jakarta: Badan Pengembangan Sumber Daya Manusia Pendidikan dan Kebudayaan dan Penjamin Mutu Pendidikan.

Kemendikbud. 2013. Modul Pedoman Pelatihan Implementasi Kurikulum 2013. Jakarta: Badan Pengembangan Sumber Daya Manusia Pendidikan dan Kebudayaan dan Penjamin Mutu Pendidikan.

Khabibah, S. 2006. Pengembangan Model Pembelajaran Matematika dengan Soal Terbuka untuk Meningkatkan Kreativitas Siswa Sekolah Dasar. Disertasi tidak dipublikasikan. Surabaya: Program Pascasarjana Unesa.

Kurniawan, A. R. 2015. Pengembangan Perangkat Pembelajaran Berbasis Pendekatan Penemuan Terbimbing untuk Melatihkan Keterampilan Proses Siswa Sekolah Dasar. Surabaya: Tesis magister pendidikan dasar tidak dipublikasikan. UNESA.

Mudhofir. 1990. Teknologi Instruksional. Bandung: Remaja Rosdakarya.

Munandar, U. 2012. Pengembangan Kreativitas Anak Berbakat. Bandung: Rineka Cipta.

National Council Teachers of Mathematics (NCTM). 2010. Why is Teaching With Problem Solving Important to Student Learning? Brief. www.nctm.org/news/content.aspx $? \mathrm{id}=25713$. Diakses pada tanggal 10 Januari 2016.

Never Ending Transfusing - Aplication Training (Net-at). 2013. http://www.mikomunitas.com/p/andreas-mzay-mi-komunitas.html\#K78O5IFLHiVjqLMv.99. Diakses tanggal 27 Januari 2016.

Nieveen, N., Akker, Van, J.D., Manbe, R., \& Plomp, T.1999. Design Approaches and Tools in Education and Training. New York: Kluwer Academic Publisher.

Nur, M \& Wikandari, P.R. 2008. Pengajaran Berpusat kepada Siswa dan Pendekatan Kontruktivis dalam Pengajaran. Pusat Studi MIPA Unesa.

Pehkonen, E. (1997). The State-of-Art in Mathematical Creativity. [Online] Zentralblatt für Didaktik der Mathematik (ZDM) The International Journal on Mathematics Education. Tersedia: http://www.emis.de/journals/ZDM/zdm 973a1. pdf . Diakses 12 Januari 2016.

Ramadin. 2013. Pembelajaran Pecahan Berbasis Masalah di Kelas IV Sekolah Dasar. Surabaya: Tesis magister pendidikan dasar tidak dipublikasikan. UNESA

Runtukahu, T \& Kandou, S. 2014. Pembelajaran Matematika Dasar bagi Anak Berkesulitan Belajar. Yogyakarta: Ar-Ruzz Media.

Shadiq, F. 2014. Strategi Pemodelan Pada Pemecahan Masalah Matematika. Yogyakarta: Graha Ilmu.

Shannon, P. 2009. Creative Thinking in Problem Solving. http://math.unipa.it/ grim/21_project/21_charlotte_ ShannonPaperEdit2.pdf. Diakses tanggal 20 Januari 2016.

Silver, E. 1997 Fostering creativity through instruction richin mathematical problem solving and problem posing. http://www.emis.de/jurnals/ZDM/zdm97a3.pdf.

Slavin, R.E. 2008. Psikologi Pendidikan Teori dan Praktik. Jakarta: PT Indeks.

Siswono, T.Y.E. (2008). Model Pembelajaran Matematika Berbasis Pengajuan dan Pemecahan Masalah untuk Meningkatkan Kemampuan Berpikir Kreatif. Surabaya: Unipres.

Spitzer, D. 1999. Learning Effectiveness Measurement (LEM).

http://www.slidesshare.net/AllisonCristiaen/lem.whi tepaper. Diakses tanggal 13 Februari 2016.

Sudarma, M. 2013. Mengembangkan Keterampilan Berpikir Kreatif. Jakarta: Rajawali Press.

Sudjana, N. 2005. Metode Statistika. Bandung: Tarsito.

Sudjana, N. 2011. Dasar-dasar Proses Belajar Mengajar. Bandung: Sinar Baru Algensindo.

Sundayana, R. 2015. Stastitika Penelitian Pendidikan. Bandung: Alfabeta

Susanto, A. (2013). Teori Belajar dan Pembelajaran di Sekolah Dasar. Jakarta: Prenadamedia Group.

Thompson, C. "Critical Thinking across the Curriculum: Process over Output". International Journal of 
Humanities and Social Science. Vol. 1 No. 9. Diakses pada tanggal 20 Februari 2016.

Torrance, E.P. 1976. Guiding Creative Talent. New Yoro: Robert E Krieger Publishing Company.

Winarni, E.S \& Harmini, S. 2014. Matematika untuk PGSD. Bandung: PT.Remaja Rosdakarya. 